\title{
IMPROVED PHOTOMETRIC METHODS FOR USE IN THE WASSERMANN REACTION \\ BY
}

\author{
DOUGLAS WHILLANS \\ From the Department of Pathology, Auckland Hospital, New Zealand
}

(RECEIVED FOR PUBLICATION, SEPTEMBER 12, 1949)

Strictly reproducible results can only be obtained in the Wassermann reaction if standardized procedures are followed for each step of this serological test. Methods already available for the standardization of sheep red cells and for the titration of haemolysin and complement have weaknesses which militate against either reproducibility or efficiency.

The standardization of sheep red cells has usually been performed either on the basis of the estimation of their haemoglobin content or of their number. As Orpwood Price and Wilkinson (1947) have pointed out, the sensitization of red cells by haemolytic immune antibody is a phenomenon which occurs at the cell surface. In other words, the total extent of cell surface, rather than the number of red cells or their contained haemoglobin, is the important factor in the reaction and should form the basis of any standardization procedure. As cell volume bears a direct relationship to cell surface, Orpwood Price and Wilkinson used the haematocrit to estimate the former in their attempt to overcome the objections to the procedures already in use. Though fundamentally sound, their method is time-consuming, which is always a serious disadvantage in routine Wassermann estimations.

In the titration of haemolysin and complement, $100 \%$ haemolysis is usually taken as the end-point for titre. As is well known, when the percentage haemolysis of red cells is plotted against the strength of haemolytic factor, the resultant curve is of sigmoid nature, so that the exact visual determination of the $100 \%$ haemolysis point is necessarily difficult. The various methods for the estimation of the $50 \%$ haemolysis point, which overcome this difficulty, involve the centrifuging of a partially haemolysed cell suspension and the estimation of the liberated haemoglobin. They again ignore the factor of cell surface, and introduce time-consuming steps into the estimation.

It has been found that the procedures detailed below overcome these difficulties. A little labour is involved in the standardization of these procedures, but once this is achieved their application to the Wassermann reaction shortens the time of the test considerably and produces results of remarkable constancy.

\section{Method of Estimating Percentage by Volume of Sheep Cells Suspended in a Suitable Diluent}

In the Orpwood Price and Wilkinson method of standardization of cell suspensions, the sheep cells are centrifuged for 10 minutes at 2,500 revolutions per minute, and it is 
stated that by that time they are packed to a constant volume in the centrifuge in use. However, using an international centrifuge type SB, size 1, at 3,000 r.p.m. (R.C.F. at tip of tube 2,000), I found that at least half an hour was required to pack the cells contained in $2-3 \mathrm{ml}$. of suspension. This is too long for routine purposes, so the following method was evolved to reduce this time to a few minutes. It is based on the measurement of the light absorption of cell suspensions under controlled conditions. The preparation of such suspensions is first described. The study of the relationship between cell volume and transmitted light follows, and is found to conform to a mathematical formula. Finally the practical application of this for use in the Wassermann procedure is verified.

The Preparation of Cell Suspensions.-Sheep cells are collected into equal parts of Alsever's solution as given by Mayer et al. (1946), with the modification that $10 \%$ of $1 / 1,000$ merthiolate is added to the suspension to inhibit bacterial growth. These cells remain stable in this fluid for many weeks when maintained at a temperature of $6^{\circ} \mathrm{C}$. In agreement with Mayer et al. it has been found that the cells should not be used within four days of collection, after which time they react in a constant manner with haemolytic antibody and complement. Haemolysis does not occur on washing unless bacterial contamination is present.

The Preparation of the Saline Diluent.-Because the $p \mathrm{H}$ of the diluent will have an effect on the volume of the red cells, this fluid must be buffered. As, too, the Wassermann reaction consists of an interlocking series of velocity reactions sensitive to hydrogen ion changes (Richardson, 1941), its reproducibility will be improved by using buffered reagents.

Mayer et al. employed a saline diluent buffered with veronal and containing magnesium and calcium ions in optimal proportions to catalyse the haemolytic reaction.


the Wassermann reaction. In order to achieve these conditions the diluent is made up in the following proportions:

$\begin{array}{lcr}\text { Sodium chloride } & \text { (A.R.) } 85 \mathrm{~g} . \\ \text { Barbitone } & \text { (B.P.) } 6.3 \mathrm{~g} . \\ \text { Sodium barbitone } & \text { (B.P.) } 3.3 \mathrm{~g} \text {. } \\ \text { Magnesium chloride, } 6 \mathrm{H}_{2} \mathrm{O} & \text { (A.R.) } 1.01 \mathrm{~g} \text {. } \\ \text { Calcium chloride, } 6 \mathrm{H}_{2} \mathrm{O} & \text { (A.R.) } 0.16 \mathrm{~g} . \\ \text { Distilled water to } & 10 \text { litres. }\end{array}$

A $p \mathrm{H}$ of 7.3 will usually result. This may be checked with a glass electrode $p \mathrm{H}$ meter, and if not correct the proportions of buffer salts can be altered slightly until the correct reaction is obtained. Barbitone is not readily soluble, but if the mixture is left standing overnight the slight undissolved scum on the surface goes into solution readily on stirring. Hereafter this buffered saline diluent will be referred to as saline.

The Washing of the Cells.-On theoretical grounds it is important to remove as much as possible of the adsorbed serum from the sheep cells before their sensitization by haemolytic immune antibody, for then this latter will be both even and complete. Adapting the method of Ayer, Dailey, and Fremont-Smith (1931) for the estimation of protein in cerebrospinal fluid to the analysis of protein in each wash fluid following centrifugation, I found that, with six volumes of buffered saline used at each wash, the concentration of protein in the supernatant wash fluid fell to under $1 / 100$ of the original concentration in four washes, and decreased irregularly thereafter. Six washes are therefore used routinely as a practical compromise. After the final wash and removal of the supernatant, the cells are ready for suspension. 


\section{The Determination of the Relation between Cell Volume and Light Transmitted}

A number of workers, especially in the field of photometric estimation of red cell counts, have shown that a close relationship exists between optical transmission and the number of cells present. Whitlock (1947) has demonstrated for sheep red cells that the cell shadow/volume ratio is a constant, whereas the haemoglobin concentration and cell volume vary independently within certain limits. It was therefore thought worth while to determine how transmission of light and cell percentage by volume of sheep cells were related.

\section{Method A}

Red cells from 20 separate sheep were collected and washed in the manner detailed above. Suspensions of approximately $5 \%$ were made in the diluent and their exact concentration by volume estimated by means of the haematocrit. The tube used for this purpose was made on the pattern of those used by Orpwood Price and Wilkinson. Its stem, calibrated with mercury, consisted of parallel-sided, heavy-walled "pyrex" tube $7.5 \mathrm{~cm}$. in length, $7.5 \mathrm{~mm}$. in diameter, and $2.1 \mathrm{~mm}$. bore. It was closed at the bottom and flared at the top into a heavy open cup $4 \mathrm{~cm}$. long and $1.6 \mathrm{~cm}$. in diameter, and was capable of carrying $4 \mathrm{ml}$. of fluid.

Ten further exact dilutions varying from $2 \%$ to $8 \%$ were made of each standardized suspension. Of each of these 200 diluted suspensions $0.1 \mathrm{ml}$. was brought up to $6 \mathrm{ml}$. with saline and their light transmissions estimated with the Coleman No. 11 spectrophotometer at $700 \mu$, using the PC-5 filter.

Calculations.-The results so obtained were found by trial and error to fit the mathematical form-

$$
C_{v}=K\left(\frac{100-T}{T}\right)^{1 / n}
$$

where $C_{v}=$ concentration of cells by volume, $T=$ percentage transmission, and $K$ and $1 / \mathrm{n}$ are constants.

This, in more useful form, reads:

$$
\log _{10} C_{v}=\log _{10} K+1 / n \log _{10}\left(\frac{100-T}{T}\right)
$$

For the conditions of the above experiment, the values of the constants were estimated graphically as $\mathrm{K}=2.04$ and $1 / \mathrm{n}=0.825$.

Thus it is established that a relationship does exist for sheep cells between concentration of cells by volume and light transmission in such a cell suspension, and that the photometric method is one which can be employed for the estimation of such concentrations.

A disadvantage of the Coleman instrument is that the estimation of low light transmission values is inaccurate. A photometer sensitive to the lower scale of transmission would enhance the accuracy of the method. One such linear vacuum tube instrument has been devised by the author, and is described in the appendix. The constants for this, in a similar standardization to that for the Coleman spectrophotometer, but using a final volume of $5 \mathrm{ml}$. in the cuvette, were found by regression methods to be $K=1.34$ and $1 / \mathrm{n}=0.796$. The analysis of variance (Table I) shows that almost all the variance is due to the linear regression on concentration by volume, and that the actual error of any observation is exceedingly small. On this basis and on that of the similarity 


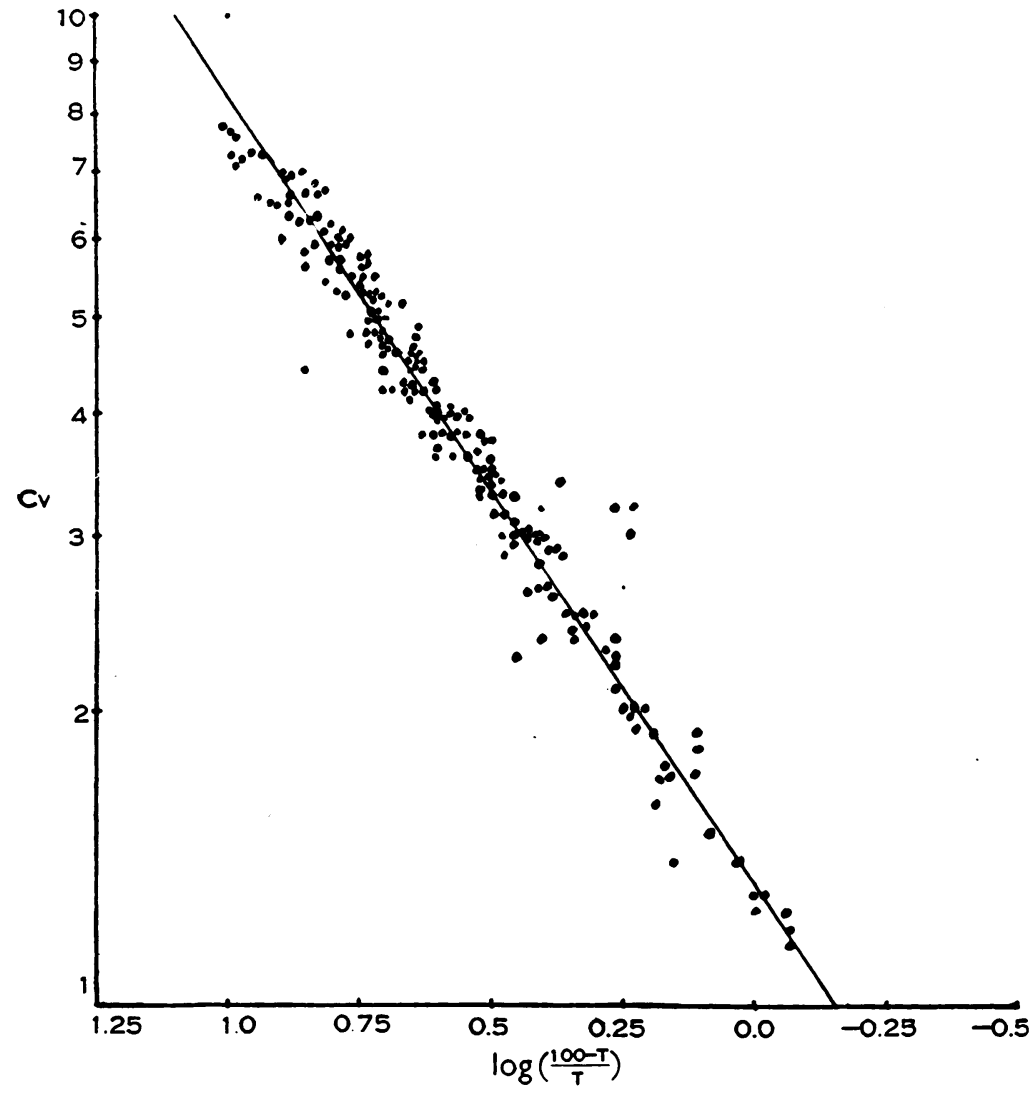

FIG. 1

between the values of $1 / n$ for the two p h o tometers, the second was accepted as a valid meas uring instrument.

For convenience, this vacuum tube photometer was employed in all the investiga tions which follow. It should be e mphasized that any linear ph ot ome ter with a suitable light filter, modified to rea d $10 \mathrm{w}$ values of light trans mission accurately, can be used in this standardization, and that the meter which has been described is merely one which, in practice, has proved to be very satisfactory.

In view of the fact that in the Wassermann reaction the red cells in the standard volume may show all grades of haemolysis from $0 \%$ to $100 \%$, it was obviously necessary to find out whether the above method still held good for the determination of the volume of cells unhaemolysed in the reaction, for then it could be applied to the standardization of haemolysin and the titration of complement. In this study, the modification of the Wassermann reaction used

TABLE I

ANALYSIS OF VARIANCE

\begin{tabular}{|c|c|c|c|c|}
\hline Source o & Variation & Degrees of Freedom & Mean Square & Significance \\
\hline $\begin{array}{l}\text { Regression } \\
\text { Error ... }\end{array}$ & $\begin{array}{l}\ldots \\
\ldots\end{array}$ & $\begin{array}{r}1 \\
198\end{array}$ & $\begin{array}{r}11.4638 \\
0.0003\end{array}$ & Highly significant \\
\hline
\end{tabular}


is that of Richardson (1940) and Vaughan (1947). The standard dose of red cells used, however, is $0.25 \mathrm{ml}$. of a $2.5 \%$ sensitized suspension.

\section{Method B}

A further series from 20 sheep was then prepared and each sample standardized to $2.5 \%$ by the haematocrit method. From each, nine preparations showing from $10 \%$ to $90 \%$ haemolysis were made. Of each of the 180 suspensions $0.25 \mathrm{ml}$. was diluted to $5 \mathrm{ml}$. with saline and their transmissions of light estimated in the photometer. The results were plotted on semilogarithmic paper with the percentage of unhaemolysed cells $\left(C_{p}\right)$ on the logarithmic axis and $\log _{10}\left(\frac{100-T}{T}\right)$ on the arithmetic axis, and the points again fell on a straight line. Therefore this method of estimating cell percentage by volume holds good under these conditions.

Calculations.-The constants, when applied to the formula

$$
\log _{10} C_{p}=\log _{10} K+1 / n \log _{10}\left(\frac{100-T}{T}\right) \ldots \ldots \ldots
$$

where $C_{p}=$ percentage by volume of cells unhaemolysed in the standard volume, were found by regression methods to be $K=18.527$ and $1 / \mathrm{n}=0.907$. The analysis of variance shows similar features to the previous one. The increased value of the constant $1 / \mathrm{n}$ is due to the presence of the liberated haemoglobin.

TABLE II

ANALYSIS OF VARIANCE

\begin{tabular}{lll|c|c|c}
\hline \multicolumn{2}{c|}{ Source of Variation } & Degrees of Freedom & Mean Square & Significance \\
\hline Regression & $\ldots$ & $\ldots$ & 1 & 19.3045 & Highly significant \\
Error.. & $\ldots$ & $\ldots$ & 178 & 0.0036 & \\
\hline
\end{tabular}

To make these relationships available for the routine Wassermann reaction, two tables must be constructed using equations (1) and (2). The first relates transmission percentage to percentage by volume of sheep cells suspended in saline $\left(C_{v}\right)$, and is used in the routine standardization of sheep cells. The second relates transmission percentage to percentage of standard cell volume, unhaemolysed $\left(C_{p}\right)$, and is used in the titration of haemolysin and complement.

\section{The Standardization of Haemolysin and the Titration of Complement}

In the titration of haemolysin and complement, $100 \%$ haemolysis is often taken as the end-point. This is likely to be inaccurate. Other workers, such as Wadsworth, Maltaner, and Maltaner (1931) have used the $50 \%$ haemolysis point for standardizing these substances using the formula attributed to von Krogh

$$
X=K\left(\frac{Y}{1-Y}\right)^{1 / n}
$$

where $\mathrm{X}=$ the amount of complement causing the haemolysis of a fraction $\mathrm{Y}$ of the cells sensitized with specific immune antibody, $K$ and $1 / n$ being constants.

In their methods, the fractions of cells haemolysed are determined in the reaction tubes by first -centrifuging the latter and then estimating the liberated haemoglobin. This procedure has the disadvantage of being time-consuming, and is theoretically unsound as the factor of cell surface is ignored. 
It has been shown that cell volume can be estimated directly in the presence of haemolysis. To make this relationship available for the above titrations equation (3) has to be modified in the following manner. If a fraction $Y$ of cells are haemolysed, they are related to $C$, the percentage of cells remaining thus

$$
\begin{aligned}
C_{p} & =100(1-Y) \text { or } \\
Y & =\frac{100-C_{p}}{100}
\end{aligned}
$$

so that on substituting for $\mathrm{Y}$ in equation (3) it becomes,

$$
\mathrm{X}=\mathrm{K}\left(\frac{100-\mathrm{C}_{\mathrm{p}}}{\mathrm{C}_{\mathrm{p}}}\right)^{1 / \mathrm{n}} \ldots \ldots \ldots
$$

The use of this equation by-passes the objections to the methods which are based on the use of equation (3).

The Standardization of Haemolysin.-Many authors - for example, Kent (1947)have found that, with increasing doses of haemolysin, the value of $1 / \mathrm{n}$ in equation (3) falls to a minimum and then increases. They have used the amount of haemolysin corresponding to this minimum as the dose for the Wassermann reaction. In the present work it was found that, for haemolysis times of 15 minutes in a water bath at $37^{\circ} \mathrm{C}$., using $0.25 \mathrm{ml}$. of $2.5 \%$ sensitized cells in the presence of graded amounts of complement, the minimum value of $1 / \mathrm{n}$ was 0.2 . However, the calculations involved in the determination of this value are much too complicated to use for routine purposes, as they have to make use of graphical constructions, or of mathematical analysis by mean squares (Kent et al., 1946) or probits (Fisher, 1948).

Wyler's (1929) method of estimating the minimal haemolytic dose of haemolysin for use in the Wassermann reaction is in essence simple and easily carried out. However, the sigmoid nature of the haemolysis curve and the visual estimation of $100 \%$ haemolysis make the end-point difficult to determine with precision. I have therefore modified the method by making use of the technique of estimating cell volume described earlier, and thereby putting this determination on an exact basis. The sample of haemolysin to be standardized is titrated according to the method of Wyler, but using $2.5 \%$ cells standardized as above. The results obtained in the photometer are plotted on semilogarithmic paper, the volume of cells haemolysed derived from equation (2) and its table, on the logarithmic axis, and the concentration of haemolysin on the arithmetic axis. This results in the expected sigmoid curve. The straight line portion of this is extrapolated to $100 \%$ haemolysis, and the concentration of haemolysin corresponding to this point taken as the minimal haemolytic dose.

Taking, as Wyler did, six times the minimal haemolytic dose for use in the Wassermann reaction, it was found that this corresponded exactly to the amount of haemolysin required to make the factor $1 / \mathrm{n}$ take the value 0.2 in equation (4). As will be shown later, this factor can be checked automatically during the routine titration. Therefore this simple procedure of titrating haemolysin is justified, because it has been shown to be accurate and at the same time avoids the necessity for complicated graphical or mathematical analyses.

The Preparation of Sensitized Sheep Cells.-Sheep cells are washed and made up in saline to a strength of $5.5 \%$ to $6 \%$ by volume and their exact percentage estimated according to the standard procedure described and by reference to the tables derived from equation (1). The amount of this suspension required to be diluted to form 
a $2.6 \%$ suspension in $100 \mathrm{ml}$. saline is placed in a wide mouthed $250-\mathrm{ml}$. bottle. Haemolysin in the correct dose, determined as described, is added to the volume of the saline required to make the final $100 \mathrm{ml}$. In order to ensure even sensitization, this latter is added in one movement to the cell suspension while it is being swirled in the $250-\mathrm{ml}$. bottle. The concentration by volume of cells in this final suspension $\left(C_{v}\right)$ is estimated as before and adjustment made, if necessary, to bring the cell volume to $2.5 \%$. A $2.6 \%$ suspension is prepared in the first place, as it is always easier to dilute to the final figure than to concentrate to it. This $2.5 \%$ sensitized suspension is placed in the water bath at $37^{\circ} \mathrm{C}$. for 15 minutes and is then ready for use in the later stages of the Wassermann reaction.

The Titration of Complement.-The estimation of cell volume $\left(C_{p}\right)$ using the $50 \%$ point is used as the basis for the standardization of a method for the titration of complement. The method of Kent et al. (1946) for 50\% haemolysis has been adapted to the estimation of cell volume and gives particularly good results. However, it is a graphical method and it was thought that, for the sake of uniformity and slightly greater accuracy, the following alternative mathematical approach merited attention.

It has been shown in equation (4) that in a complement titration the amount of complement can be related to the cell volume. It has also been shown that the factor $1 / \mathrm{n}$ can be stabilized at 0.2 , so that we can now write equation (4) thus

Now let

$$
\begin{gathered}
X=K\left(\frac{100-C_{p}}{C_{p}}\right)^{0.2} \\
\left(\frac{100-C_{n}}{C_{p}}\right)^{0.2}=Z
\end{gathered}
$$

then $X / Z=K$

On examining equation (5), it is seen that if $C_{p}=50$ (that is, if $50 \%$ of the cells by volume in the haemolytic reaction remain unhaemolysed), $X=K$. This means that if the value of $\mathrm{K}$ can be estimated, the dose of complement required for use in the Wassermann reaction can be defined exactly. The estimation of this constant is achieved by carrying out a titration of complement and determining the values of $Z$ (equation 6 ) for each value of $X$. The quotient $X / Z$ is then $K$, and is recorded for each tube of the titration.

The standard method used for titrating complement, which is, in fact, a modification of Wyler's technique, is now described in detail, as the values of $X$ and $Z$ will vary according to the quantities of the reagents used and the conditions under which they are allowed to react.

Preparation of Complement.-Twelve exsanguinated guinea-pigs provide each pool of complement. This is dosed into $5 \mathrm{ml}$. quantities in 4 in. by $\frac{1}{2}$ in. test-tubes, corked and stored at $-16^{\circ} \mathrm{C}$. In this state the complement has been shown to be stable for many weeks. When required for use, a tube is thawed on the bench and the complement diluted to $50 \mathrm{ml}$. with saline, thus providing a 1 in 10 dilution. This is kept at $6^{\circ} \mathrm{C}$. until actually required for use.

Method for Titration of Complement.-Two rows of ten 4 in. by $\frac{1}{2}$ in. test-tubes are set up in a rack and saline is pipetted into the back row, proceeding from left to right in the series $2.6,2.8 \ldots \ldots 4.4 \mathrm{ml}$. Into the front row is pipetted $0.5 \mathrm{ml}$. of saline. Into each tube of the back row is now pipetted $0.25 \mathrm{ml}$. of 1 in 10 
complement in saline and, beginning at the tube with the greatest dilution and working down to that with the least, the contents are well mixed. Then $0.25 \mathrm{ml}$. is transferred with a clean pipette from each of these tubes to the corresponding front one. The rack is warmed for two minutes in the water bath at $37^{\circ} \mathrm{C}$., and $0.25 \mathrm{ml}$. of the standardized sensitized cells, also warmed to $37^{\circ} \mathrm{C}$., are added to each tube of the front row. These are shaken briefly at the time of addition to ensure even distribution of complement among the red cells. The complement should not be warmed for more than two minutes because of its instability in high dilutions of serum. When the addition of cells is complete, the rack is shaken two or three times and returned to the water bath for 15 minutes, during which time it is removed and shaken again on two occasions. When incubation is complete $4 \mathrm{ml}$. of saline are added to each tube of the front row and the light transmissions determined for each suspension.

Calculation of Factors.-The values of $\mathrm{X}$ for each of the 10 tubes are calculated as follows. Let $\mathrm{R}$ be the volume of saline in $\mathrm{ml}$. initially present in any tube of the back row. Then the amount of complement, $X$, in each of the front tubes will be,

$$
\frac{0.25 \times 0.25}{10(\bar{R}+0.25)} \mathrm{ml} \text {. }
$$

Now, while knowledge of this quantity of complement is essential in theoretical calculations, for routine purposes the total amount of complement to be made up for any session is required to be known. For convenience, this can be expressed as the volume of 1 in 10 complement which has to be diluted to $100 \mathrm{ml}$. so that $0.25 \mathrm{ml}$. will contain one $50 \%$ dose. It will be readily appreciated that the relationship between the amount of complement in the front tubes of the rack (the actual titration row) and the $100 \mathrm{ml}$. of final complement is as $1: 4,000$, i.e.

$$
X=\frac{25}{R+0.25}
$$

Thus the values for $\mathrm{X}$ for each of the ten tubes can be tabulated.

To avoid the labour of calculating the values of $Z$ from equations (2) and (6) for each light transmission figure $T$ whenever complement is to be titrated, a table relating $\Gamma$ to $Z$ is prepared. The comprehensive tables of Ecker and Hiatt (1949) may be used for values of the function $\left(\frac{Y}{1-Y}\right)^{1 / n}$, for as $C_{p}=100(1-Y)$, these tables apply to the formula $\left(\frac{100-C_{p}}{C_{p}}\right)^{1 / n}$ also.

In view of the fact that the value of $1 / \mathrm{n}$ in equation (6) is 0.2 , and that $C_{p}$ can be calculated for each value of $T$ from equation (2), a table of $Z$ can be prepared for each possible value of $T$. From this the actual values of $Z$ for the light transmission figures in the complement titration are at once obtained.

For the relation $K=X / Z$, ten separate values of this constant can now be obtained. This represents ten separate estimates of the $50 \%$ unit of complement. On comparing the value of the unit of complement standardized by the original Wyler method with that of the $50 \%$ unit derived as above, it was found that three Wyler units were approximately equal to eight $50 \%$ units. Hence on adding the values of $\mathrm{K}$ for any successive eight out of ten tubes, the amount of 1 in 10 complement required to be diluted to $100 \mathrm{ml}$. to give eight $50 \%$ complement units is obtained. The eight values of $\mathrm{Z}$ are selected to be as near mid-range as possible. 
TABLE III

TABLE OF TITRATIONS

\begin{tabular}{c|c|c|c}
\hline $\mathrm{R}$ & $\mathrm{X}$ & $\mathrm{Z}$ & $\mathrm{K}$ \\
\hline 2.6 & 8.8 & 1.34 & 6.6 \\
2.8 & 8.2 & 1.26 & 6.5 \\
3.0 & 7.7 & 1.25 & 6.15 \\
3.2 & 7.25 & 1.22 & 5.9 \\
3.4 & 6.85 & 1.09 & 6.2 \\
3.6 & 6.5 & 1.09 & 5.8 \\
3.8 & 6.2 & 1.08 & 5.7 \\
4.0 & 5.9 & 1.00 & 5.4 \\
4.2 & 5.6 & 0.95 & 5.7 \\
4.4 & 5.4 & & \\
\hline
\end{tabular}

Table III gives a worked example of an actual titration using this method.

Adding the values of $K$ for tubes $R 3.0$ to $R$ 4.4, inclusive, gives the value 46.45 . This is the amount in ml. of the 1 in 10 complement which, when diluted to $100 \mathrm{ml}$. with saline, will contain eight $50 \%$ units in $0.25 \mathrm{ml}$.

An additional reason why this method of estimating the $50 \%$ unit of complement is valuable is that it can be seen by inspection if the factor $1 / \mathrm{n}$ determining the slope of the complement titration line is approximately 0.2 . If it is not, the factor $\mathrm{K}$ will vary continuously, instead of around a central figure, indicating that the haemolysin needs re-titrating.

This method, when applied to the Richardson-Wyler modification of the Wassermann reaction, has proved satisfactory in routine use over the past year, during which time approximately 10,000 sera have been examined in daily sessions. It has been responsible for a great increase in speed and accuracy in performance of the test.

It makes use of the estimation of cell volume and so takes account of cell surface, thereby placing the estimations on a sound theoretical basis. The method involves the reading, in a photometer, of light transmission values of sheep cells suspended in a suitable diluent, and the obtaining of certain figures by reference to four tables. From these, by simple calculations, the sheep cells, haemolysin, and complement may be standardized exactly and in the matter of a few minutes.

Some indication of the accuracy of the standardization procedure in given by the fact that the value of $1 / \mathrm{n}$ in 20 unselected, routine, serial complement titrations was calculated by the method of mean squares and was found to be $0.206 \pm 0.017$. The rapidity of standardization makes well worth while the initial labour involved in the preparation of the tables. Finally, the method has the great advantage that a continuous check can be kept on the activity of both haemolysin and complement without any additional labour being involved.

\section{Summary}

Improved photometric methods for the standardization of sensitized sheep cells and haemolysin and for the titration of complement for use in the Wassermann reaction are described. They involve the measurement of red cell volume, which is considered the factor most closely related to the cell surface, the point at which the haemolytic reaction occurs. 
In the interests of accuracy and speed these methods are recommended for adoption in the routine performance of this Wassermann reaction.

I wish to thank Miss N. R. L. Davies, B.Sc., for her willing and able technical assistance during this work, Dr. J. L. Pinniger for his helpful criticism and advice, and Mr. H. R. Thompson, M.Sc., of the Applied Mathematics Laboratory, Wellington, for help with the statistical analyses.

\section{REFERENCES}

Ayer, J. B., Dailey, M. E., and Fremont-Smith, F. (1931). Arch. Neurol. Psychiat., Chicago, 26, 1038. Ecker, E. E., and Hiatt, C. W. (1949). Amer. J. clin. Path., 19, 141.

Fisher, J. W. (1948). J. Immunol., 60, 85.

Kent, J. F. (1947). Science, 105, 316.

- Bukantz, S. C., and Rein, C. R. (1946). J. Immunol., 53, 37.

Mayer, M. M., Osler, A. G., Bier, O. G., and Heidelberger, M. (1946). J. exp. Med., 84, 535.

Morgan, R. H., and Weinhouse, S. (1940). J. Lab. clin. Med., 26, 416.

Orpwood Price, I. N., and Wilkinson, A. E. (1947). Brit. J. vener. Dis., 23, 124.

Radiotronics. Technical Bulletin No. 109 (1941). Amalgamated Wireless Valve Company, Sydney. Richardson, G. M. (1940). Brit. J. vener. Dis., 16, 166.

- (1941). Lancet, 2, 696.

Vaughan, A. C. T. (1947). Brit. J. vener. Dis., 23, 77.

Wadsworth, A., Maltaner, E., and Maltaner, F. (1931). .J. Immunol., 21, 313.

Whitlock, J. H. (1947). Blood, $2,463$.

Wyler, E. J. (1929). Spec. Rep. Ser. med. Res. Coun., Lond., No. 129.

\section{A BRIDGE CIRCUIT, VACUUM TUBE PHOTOMETER}

The circuit diagram (Fig. 2) of the pentode, bridge balance photometer which was used in the photometric methods described is self explanatory. It is similar to one in a Radiotronics Bulletin (1941) and uses some of the constructional ideas of Morgan and Weinhouse (1940).

The type 926 R.C.A. photocell was used as it was on hand, but no doubt other types, especially those sensitive in the red part of the spectrum, would be as satisfactory. It will be noticed that the $0-50$ microammeter is normally shunted so that it in effect a 0-250 microammeter, thus preventing accidental overload of the meter. On pressing the "multiplier key," it reverts to its original range, thus making it simple to read values of transmission under $20 \%$, which are thereby multiplied by a factor of 5 . The meter still remains linear over this part of the scale.

In wiring, normal amplifier practice was followed, all earthing being brought back to a common point. The wiring was with P.V.C. cable which completely stopped any instability due to leakage. The screened phototube was mounted on a polystyrene block immediately above the input grid. The grid load resisters and their associated condensers were wired direct to the earthed valve shields.

The Coleman square cuvette was used and was illuminated by a small dental bulb with fused-in lens. This was mounted almost in contact in the wall of the cuvette well. Between the cuvette and the photocell was mounted an Ilford tri-colour red filter which has a density of no more than 0.1 at wavelengths over $620 \mu$, thus minimizing the effect of haemoglobin on the overall transmission. 


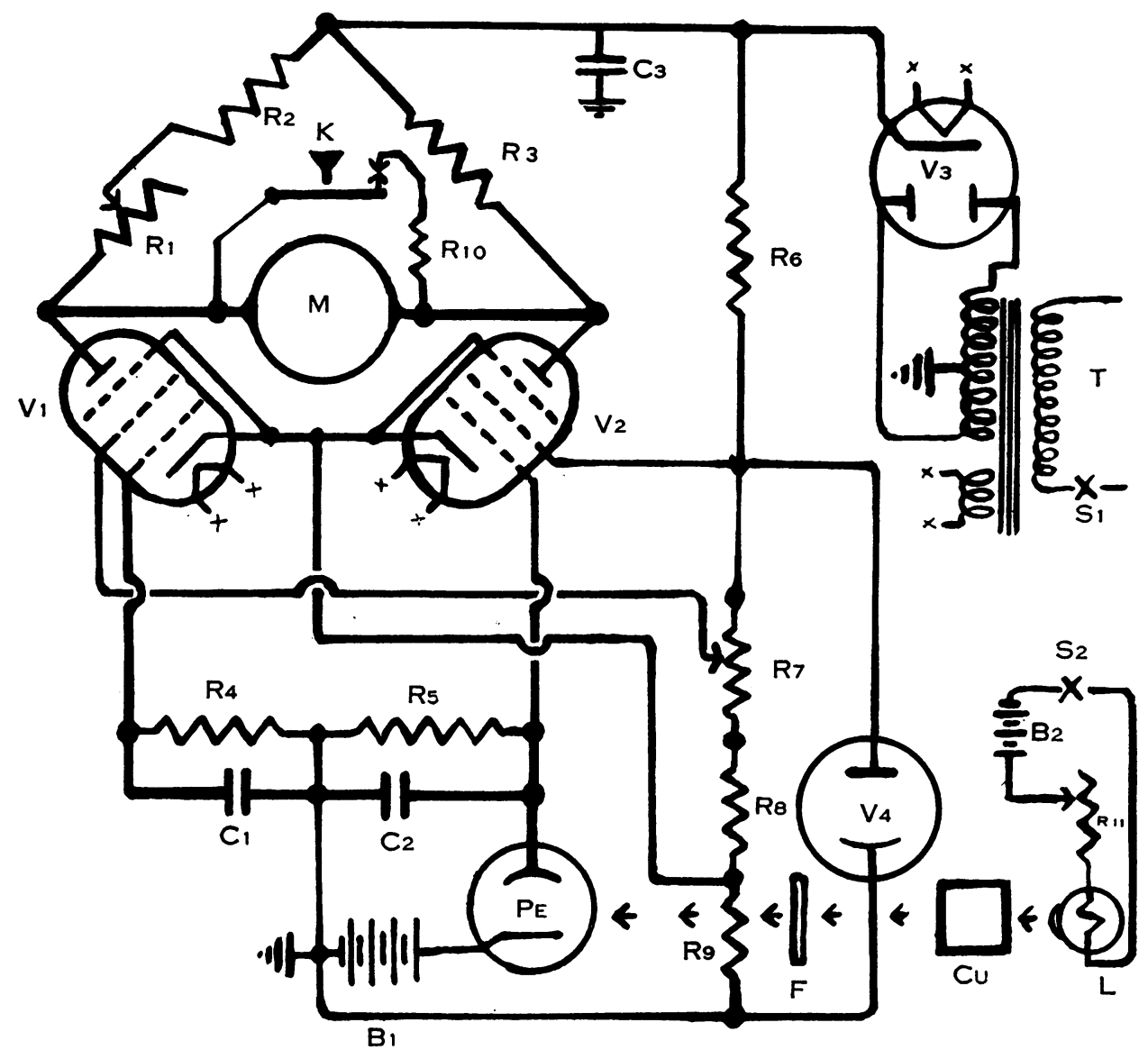

Fig. 2

$\mathrm{B} 1=22.5 \mathrm{~V}$. miniature dry battery.

$\mathrm{B} 2=3 \mathrm{~V}$. heavy duty dry battery.

$\mathrm{C} 1, \mathrm{C} 2=0.01 \mathrm{mfd}$. mica condenser.

R5 $=10$ megohms, $\frac{1}{2}$ watt.

$\mathrm{R} 6=2,500$ ohms, 2 watts.

$\mathrm{R} 7=10,000$ ohms, 1 watt.

$\mathrm{R} 8=2,500$ ohms, 1 watt.

R9 $=300$ ohms, 1 watt. condenser.

$\mathrm{Cu}=$ Cuvette.

$\mathrm{F}=$ Ilford tri-colour red filter.

$\mathrm{K}=$ "Multiplier" key ("push to talk"

$R 10=X 5$ shunt to suit meter.

$R 11=20$ ohms filament rheostat.

$\mathrm{S} 1, \mathbf{S} 2=$ On/off switch. switch).

$\mathrm{L}=$ Dental torch bulb with fused-in lens.

$\mathbf{M}=0-50$ microammeter.

$P E=$ Type 926, vacuum phototube.

$\mathrm{R} 1=1,000 \mathrm{ohms}, 1$ watt.

$\mathrm{R} 2, \mathrm{R} 3=50,000$ ohms, 1 watt.

$\mathrm{T}=$ Power transformer, 230 V.A.C. primary; $150,0,150$ V., 40 mills.; 6.3 V., 2 A. secondaries.

$\mathrm{V} 1, \mathrm{~V} 2=$ Type $6 \mathrm{~J}$ 7-G valve.

$\mathrm{V} 3=$ Type 6 X 5-GT valve.

$\mathrm{V} 4=$ Type $V R \quad 105-30$ voltage regulating 